\title{
AFFILIATED SOCIETY.
}

\section{SUTTON \& DISTRICT MEDICAL SOCIETY (Season 1937-1938).}

Friday, DeCEMBER 3rd.

Speaker: Professor G. Grey Turner, M.S., F.R.C.S.

"Surgical Talk."

FrIDAY, JANUARY 14th.

Lecturer: J. Everidge, Esq., F.R.C.S.

CRESSY MEMORIAL LECTURE.

"Pyuria-its significance and its treatment."

FRIDAY, FEBRUARY 4th.

Speaker: Dr. T. C. Hunt, F.R.C.P.

"Prontosil-and others."

FRIDAY, MARCH 4th.

Speaker: Dr. J. L. Livingstone, F.R.C.P.

"Hay Fever and other Allergic Conditions."

FRIDAY, MARCH 18th.

Cinema show of some Medical and Scientific Films.

FRIDAY, APRIL 1st.

Speaker: Dr. H. C. Cameron, F.R.C.P.

"Streptococcal Infections in Childhood:"

FRIDAI, MAY 6th.

ANNUAL DINNER, 7.45 for 8 p.m. The visiting speakers will be guests of the Society.

Meetings are held at 8.30 for 8.45 sharp at The "Greyhound" Hotel, Carshalton, unless otherwise stated.

"Greyhound" 'Phone: Wallington 1511.

Theodore H. Whittington (Hon. Sec.).

\section{REVIEWS.}

\section{PROTOFORMOTHERAPY IN TREATMENT \& PREVENTION. \\ Fifteen Years of Research on New Scientific Bases of Therapeutics.}

By DR. N. E. Ischlondsky. Henry Kimpton. 1937. 21/- net.

This book is based on three lectures given at the University of Cairo in March, 1936. The various tissue cells differ in many ways but each possesses primitive or protoform properties which are common for all protoplasm. The action of any agents acting upon these protoform properties is general in character, the effect extending over every tissue and organ.
Protoformotherapy has as its aim the stimulation of these natural protective capacities of the organisms. The most powerful of such stimulants is apparently obtained by the action of embryonic tissue extract on the genital pro-hormone in vitro. The first chapter deals with the action of this protoformative substance on guinea-pigs, senile, debilitated and cæhectic. In all considerable improvement was obtained and in addition a prolongation of life over 30 to 35 per cent. of the average duration was noted. The second chapter deals with the use of the extract in man and is documented by thirty case histories chosen from over eleven hundred patients treated by the author and his collaborators. The conditions treated 
include nephrosclerosis, pernicious anæmia, dyspituitarism, diabetes, tuberculosis and many others. The case histories supplemented by photographs and X-ray reproductions include confirmatory reports from the grateful patients: but in addition objective proofs of recovery are given such as reduction of blood pressure, increase of hæmoglobin and red cells and in one case enormous improvement in cataract of each eye with increase of vision from $6 / 24$ (R) and $6 / 12$ (L) to $6 / 6$ in each eye. The third chapter is concerned with the effect of the extract on premature senility of any particular system in the body while the last is concerned with the importance of the extract in the prevention of carcinoma.

Sufficient has been said to indicate the important claims made for this form of treatment which apparently has special influence on that popular member of the endocrine orchestra, the pituitary. One would like to hear of the experiences of other physicians with this method of stimulating the vis medicatrix naturce. Although in places the style is difficult, the author puts his case well and succeeds in stimulating the mental processes of the reader.

\section{A TEXT-BOOK of OPHTHALMIC OPERATIONS.}

By Harold Grimsdale, M.B., F.R.C.S. and ElMORE BREWERTON, F.R.C.S. Bailliére, Tindall \& Cox. 1937. Price $17 / 6$.

In this, the third edition, of perhaps the most widely known English book on Ophthalmic Operations, the authors have excised much that held interest only in the development of the operative surgery of a specialized branch. Standard operations long in general use are clearly described with excellent illustrations. Even now the book contains descriptions of operative modifications seldom used, although possibly necessary from an examination point of view.

Modern operative advances, especially for detachment of the retina, are described although not in the same detail as with many older operations. So large a literature has been built up around this specialized work that the student can hardly expect to find the subject fully described in a text-book of this size. The bibliography, however, is full and should be sufficient for a reader wishing further to pursue any of the modern lines rather briefly touched upon.

\section{Forthcoming Medical Books.}

H. K. LEWIS \& CO. Ltd.

136, Gower Street, London, W.C.1.

"A Guide to Veterinary Parasitology for Veterinary Students and Practitioners," by T. Southwell, D.Sc., Ph.D., and A. Kirshner, M.B., Ch.B. With 88 illustrations and 12 diagrams. Demy 8 vo. Price 7s. 6d. net.

"Eyestrain and Convergence," by N. A. Stutterheim, M.D. (Rand.). Crown 4to. Price 7s. 6d. net.

"The Sanitary Inspector's Handbook." A Manual for Sanitary Inspectors and other executive Public Health Officers.
By Henry C. Clay, F.I.S.E. Third Edition revised and enlarged, 95 illustrations. Price 16s. 6d. net.

"Diseases of the Ear, Throat and Nose," (General Practice Series). By J. D. McLaggan, F.R.C.S., Surgeon, Central London Throat and Ear Hospital, etc. With 9 plates and 135 text illustrations. Demy 8vo. Price 15s. net.

"The Principles and Practice of Rectal Surgery," by W. B. Gabriel, M.S., F.R.C.S. Second Edition. With 9 coloured plates and 162 illustrations. Royal 8vo. Price 28s. net. 